ments of both $\mathrm{Rl7}$ and $\mathrm{Q} \beta$ RNA molecules, but what is really needed is the complete sequence of one of them. In the early days of work with the RNA phages there seemed no reason to prefer one phage to another. Only after Spiegelman's group discovered that the replicase of $Q \beta$ is far more stable in the test-tube than the replicases of the other RNA phages did the enzymologists switch to $\mathrm{Q} \beta$ while the geneticists continued with RI7 and its elose relatives. It is to bo hoped that R17 and $\mathrm{Q} \beta$ RNA do not differ in anything significant. Argetsinger Steitz and Hindley and Staples, for example, have proved that at least the ribosome binding sites for the coat protein genes of the two phages have much in common. On the other hand, the sequence immediately preceding the AUG codons at positions 62 to 64 and 102 to 104 in the $Q \beta$ RNA do not closely resemble the ribosome binding sites of the R17 coat protein and assembly protein. It seems likely that all species of bactcriophage RNA will prove to have considerable regions of base paired secondary structure, double stranded loops from the single stranded chain. But the sooncr efforts are concentrated on just one of these phages, the sooner a complete sequence will be available. And the best choice should be $\mathrm{Q} \beta$ because, with the replicase available, molecules can be tailor-made for sequence analysis.

\section{CONTINENTAL DRIFT}

\section{Ancient Seafloor Spreading}

from our Geomagnetism Correspondent

TF, as is likely, continental drift is intermittent rather than continuous, there is no rcason why drift should continue after a period of dormancy in precisely the way it left off. Thus if continental drift is a result of the spreading of the ocean floor away from mid-oceanic ridges, a particular ridge may become inactive during a non-drift phase and remain so when other ridges bccome active again. All this implies the possibility of ridges that are at present dormant or extinct.

The Dampier Ridge may be a case in point (Van der Linden, Earth Planet. Sci. Lett., 6, 483; 1969). It follows a north-south route about $1,200 \mathrm{~km}$ long through the northern Tasman Basin which separates the east coast of Australia from the Lord Howe Rise. The latter is a geosynclinal belt which as such must, at the time of its formation in the Palaeozoic, have becn adjacent to its sediment source area. This could only have becn Australia. Thus the implication is that the Tasman Basin was formed later than the Palaeozoic. The presenco of the Dampier Ridge is then circumstantial evidence in favour of a spreading origin for the Tasman Sea. Further, the ridgo lies roughly halfway between two chains of parallel sea. mounts, the positions of which have long been regarded as anomalous. This geographical relationship suggests a causal relationship.

Van der Linden has obtained important new evidence from cast-west magnetic profiles across the Dampier Ridge and the adjacent ocean floor. Although of lower amplitude, the magnetic pattern is very similar to those observed over active mid-oceanic ridges. In particular, it shows a high central anomaly together with symmetry about the ridge. Although the pattern becomes irregular where the ridge merges with the foothills of the Lord Howe Rise, it clearly forms a series of north-south parallel anomalies.

The magnetic anomaly pattern thus supports the idea that the Dampier Ridge is similar in origin to other mid-oceanic ridges. On this interpretation the seamounts would have formed at the ridge crest and then moved away from the ridge as a result of seafloor spreading since the Palaeozoic. The known age of volcanic activity on Lord Howe Island, situated between the Dampier Ridge and Lord Howe Rise, suggests further that this spreading, and thus the opening of the Tasman Sea, took place during the Tertiary. Supporting evidence for spreading may also be seen in the morphology of the sea's western margin. The unusual steepness of Australia's eastern continental slope strongly suggests that it is a rift margin. There is, of course, no question that the Dampicr Ridge is still active because it is completely aseismic.

Other similar features in the western Pacific present further opportunities to test Van der Linden's interpretation. The South Fiji Basin between New Caledonia, Fiji and New Zealand also possesses a central northsouth aseismic ridge, the Three Kings Ridge. The Kyushu-Palau Ridge likewise traverses the Philippine Basin. Other explanations of these features are possible, notably the break-up of original continental crust suggested by Beloussov and Ruditch (J.Geol., 69, 647 ; 1961). But the observation of parallel magnetic anomalies across these ridges would strongly favour the ancient spreading hypothesis.

\section{CONTINENTAL DRIFT \\ Evidence from Rare Earths}

\section{from our Geomagnetism Correspondent}

FURTHER proof, if such be needed, of the importance of geochemistry in geophysical interpretation has been provided by Schilling (Science, 165, 1357; 1969), who has analysed five submarine tholeiitic basalts from the Red Sea. Evidence from magnetic, gravity, seismic and heat flow studies strongly suggests that the Red Sea is a region of young, active ocean floor spreading. If this is so, the axial trough should be similar to the central trough of mid-oceanic ridges and the new seafloor produced there should be of similar origin and nature. Geochemical evidence of similarity between Red Sea and mid-oceanic ridge basalts would thus support current interpretations of Red Sea behaviour.

Using neutron activation. Schilling analysed the five basalt fragments for the rare earth elements ${ }_{57} \mathrm{La}$ to ${ }_{71} \mathrm{Tu}$ and ${ }_{39} \mathrm{Y}$. The abundance of each element ("enrichment factor") was then expressed relative to a common reference, the average of ordinary chondritic meteorites. The results showed that the five Red Sea basalts were closely similar. The average abundance pattern was of a progressive increase in enrichment factor from the light to the heavy rarc earths, but with the rate of increase falling off rapidly with increasing atomic number.

The importance of this pattern is that it is very similar to those obtained from tholeiitic basalts dredged from the East Pacific Rise, the Mid-Atlantic Ridge and the Carlsberg Ridge. But it is very different 